\title{
Institutional Design and the Use of Direct Democracy: Evidence from the German Länder
}

\author{
CHRISTINA EDER, ADRIAN VATTER and MARKUS FREITAG
}

Despite growing interest in direct democratic institutions, the empirical evidence on the relationship between institutional design and the actual use of popular rights remains rather sparse. The authors use a novel data set on institutional openness and test its link to the number of popular initiatives in the German Länder for the period of 1997-2005. Their empirical analysis reveals a strong and robust negative effect of higher institutional requirements on the number of popular initiatives in the 16 German Lander; whereas other factors appear to be of minor importance. They thus come to the conclusion that the comparatively high institutional hurdles in the Länder impose costs of. initiation, thereby limiting the number of popular initiatives.

With the French and Dutch rejection of the European Constitutional Treaty in 2005 and the Irish 'No' to the Treaty of Lisbon in 2008, direct democracy suddenly made its way into headlines around the world. Apart from these big events and especially in the last two decades, direct democratic instruments - particularly the popular initiative - have become means to be used by the people to influence day-to-day politics from the bottom up. Of the 30 European states that adopted a new constitution after the end of the Cold War, only three do not include any rights of direct democracy. ${ }^{1}$ In Switzerland, the bastion of direct democracy (Fossedal 2002), referendums and initiatives are widely used on all levels of government (e.g. Trechsel 2000; Vatter 2002). In the USA, around 70 per cent of the population have access to these instruments on the subnational and local levels (Matsusaka 2004: ix). Although the German Basic Law does not provide for the instruments, direct democracy has spread at the Land and local levels since Reunification.

Correspondence Address: christina.eder@uni-konstanz.de; vatter@ipz.uzh.ch; markus.freitag@uni-konstanz.de

Konstanzer Online-Publikations-System (KOPS)

URN: http://nbn-resolving.de/urn:nbn:de:bsz:352-opus-108630 URL: http://kops.ub.uni-konstanz.de/volltexte/2010/10863 
However, although direct democracy is of considerable relevance and its history can be traced back to ancient Athens, there is no common definition of the term. At the same time, the instruments assigned to the notion also vary markedly. For the purpose of this article, 'direct democracy' refers to all tools that provide voters with an unmediated, but temporary say in the political decision-making process. Direct democracy is understood as complementing representative government and, consequently, periodic elections are not subsumed under the definition. Included are then all popular decisions on issues, as launched either by the legislature or government or by the people. The popular initiative fulfils the criterion of unmediated but temporary influence. It is a tool to be initiated by voters from the bottom up. ${ }^{2}$ It permits people to circumvent the standard representative system of decision-making and thus allows them to play an active role in government (Suksi 1993). Results are generally unpredictable and not subject to government regulation (Smith 1976); but they are politically and legally binding (Hug and Sciarini 2000).

While a wide range of research deals with the consequences of direct citizen involvement (Cronin 1989; Freitag and Vatter 2004; Hug and Tsebelis 2002; Kirchgässner et al. 1999; Matsusaka 1995; Stutzer and Frey 2000; Suksi 1993), the question of how to explain the frequency of use remains largely unanswered. This article aims to examine this question for the popular initiative in the German Länder. The focus of the analytical interest is on the impact institutional designs have on the use of direct democratic instruments. The central assumption is that institutional openness, namely signature requirements and circulation time (rules-in-form), determines the use of the popular initiative (rules-in-use). Results vary concerning the Swiss cantons and US states (e.g. Barankay et al. 2003; Magleby 1994; Vatter 2002). For the German Länder, empirical evidence is considerably lacking. Although some studies argue that the relation holds for the Länder (see Kampwirth 2003; Rehmet 2002; Weixner 2002), none puts the claim to an empirical test. A study of the influence of regulatory frameworks on initiative frequency therefore seems a necessary step in narrowing the existing research gap.

The discussion is structured as follows: a short overview of the history of the popular initiative is presented in the next section and is followed by a description of legal requirements and initiative frequency. Section two then focuses on the synthesis of the theoretical background on institutional settings and direct democracy. The research design is outlined in section four, together with a list of control factors used in the calculations. This is followed by the empirical results. The analysis is conducted in three steps. First, bivariate correlations between different institutional requirements and initiative frequency are computed to find the indicator with the most explanatory power. This variable is then used in multiple OLS regressions to determine if the relation holds, while controlling for other factors. The results are tested for robustness and validity. The final section summarises the findings with some concluding remarks. 


\section{The German Länder and the Popular Initiative}

This article analyses direct democracy in the German Länder from a comparative macro-quantitative perspective. A within-nation evaluation (Snyder 2001) seems viable: the Länder show considerable variance with regard to the use and design of their direct democratic instruments, as they are responsible for establishing their own regulatory frameworks in this field. They can thus become 'laboratories' for other territorial entities and even the central government (Möckli 2007; Vatter 2002). ${ }^{3}$

Direct democracy can be analysed from two different angles. First, one can concentrate on the regulatory frameworks specified in the respective constitution or laws. These rules-in-form cover, for example, signature requirements and circulation time and measure the institutional openness of the popular initiative. Second, one can look at the actual use of initiatives in other words, rules-in-use. ${ }^{4}$ The present article combines both perspectives to assess the impact of institutional openness on the number of initiatives in the German Länder.

Since the late 1940s, direct democracy has been a matter of debate in West Germany. In the constitutional committees, the question arose as to whether people should be granted an unmediated say in day-to-day politics. The answers to this question differed widely. While the German Basic Law was designed to be purely representative, ${ }^{5}$ seven out of 10 of the western Länder constitutions provided their citizens with instruments of direct democracy. ${ }^{6}$ However, it was not until 1989 that the instruments got much use: in total, 27 initiatives were submitted, almost half of them in Bavaria. The rate of success was quite low; only two initiatives made it to the ballot and both were rejected by the voters. Since Reunification in 1990, a drastic change can be observed. The five new Länder quickly introduced the initiative as a consequence of the active role the population played in overthrowing the GDR regime. In Schleswig-Holstein, the introduction can be attributed to the "Barschel affair" that damaged public trust and heightened voter demands for more civic control of political decision-making (Magin and Eder 2007; Wiegand 2006). The last Land to provide for the instrument was Berlin in 1997. Currently, citizens in all 16 Länder have, at the very least, the possibility to launch popular initiatives.

The instrument has been used for a variety of issues. While the subject matter of some initiatives has been rather trivial, such as those aiming to extend opening hours of video stores (Hamburg 2000, North RhineWestphalia 2005) or the rights of horseback-riders in the forests of Brandenburg (2000), there have been very influential ones that intended to amend Land constitutions. In 1997, the popular initiative was successfully used in Bavaria to abolish the second parliamentary chamber. ${ }^{8}$ Furthermore, the people of Hamburg attempted to change their municipal electoral system and to strengthen direct democracy via the popular initiative in $2005 .^{9}$ 
An increasing number of studies on direct democracy in Germany reflect its growing importance. The most detailed description of developments and practice can be found in Rux (2008) or Eder and Magin (2008b). Other examples include Kost (2005), Schiller (2002), Schiller and Mittendorf (2002) and Weixner $(2002,2006)$. Most of the research, however, is undertaken from a rather descriptive perspective. There are of course exceptions: for example, Hernekamp (1979), Heußner (1994) and Troitzsch (1979) examine the Länder in relation to other subnational entities.

\section{Institutional Openness: The Initiative Process}

As mentioned above, the popular initiative (Volksgesetzgebung) is a bottomup instrument that can be used by voters to influence the political process. In the Länder, it generally occurs along three stages:

1. Initiation (Einleitungsphase);

2. Circulation (Volksbegehren);

3. Ballot vote (Volksentscheid).

To officially start the process, initiators submit their request, together with the specified number of signatures, to the respective authority. Depending on the Land, this could be either the Land election supervisor or the President of the Land parliament. The request is then reviewed with regard to legal and financial provisions. For the circulation stage, a considerably higher number of signatures must be collected in a shorter period of time. If the threshold is reached, voters are asked to decide on the matter at the ballot. With the exception of Bremen, the parliament is allowed to issue a counterproposal to the citizen ballot measure. Alternatively, the parliament can always decide to take on the issue itself prior to the final vote.

The following sections provide an overview of regulations and a presentation of the institutional indicators used in the analysis. The focus is on the circulation stage, as it is the decisive stage in the initiative process for several reasons. First, the initiators already cleared the first hurdle by getting their request successfully revised for legal and financial provisions. Second, differences in legal regulations make it difficult to compare the Länder in the initiation stage. ${ }^{10}$ Third, the circulation stage also determines if the matter actually qualifies for the ballot. If the initiators fail to gather the required number of signatures, which can be up to 20 per cent of the voting population, the procedure ends immediately. As only nine of the 79 officially registered initiatives actually made it to the ballot in the period under consideration, it is clear that the circulation stage is crucial for the future of the requests. Moreover, the number of actual ballot votes is too low to run an analysis such as the one in this paper. 


\section{Circulation Stage}

If the initiators manage to officially register an initiative, i.e. meet the signature requirement in the initiation stage and their request is not denied due to legal or financial reasons, the circulation stage is reached. Here, a considerably higher number of signatures has to be collected in a shorter amount of time. As columns three to five of Table 1 show, requirements vary from Land to Land. All institutional values are averages for the time period 1997-2005 and thus cover changes in qualifications.

The third column in Table 1 presents the quorum as the percentage of those entitled to vote in Land elections. Brandenburg features the lowest quorum of 3.8 per cent, followed by Schleswig-Holstein with 5 per cent. The

TABLE 1

THE POPULAR INITIATIVE IN THE GERMAN LÄNDER (CIRCULATION STAGE)

\begin{tabular}{lccccc}
\hline & \multicolumn{3}{c}{ Rules-in-Form } & \\
\cline { 3 - 5 } & $\begin{array}{c}\text { Introduction } \\
\text { of the Popular } \\
\text { Lnitiative }\end{array}$ & $\begin{array}{c}\text { Quorum } \\
\mathbf{( \% )}\end{array}$ & $\begin{array}{c}\text { Circulation } \\
\text { Time (Days) }\end{array}$ & $\begin{array}{c}\text { Mobilisation } \\
\text { Coefficient }\end{array}$ & $\begin{array}{c}\text { Rules-in-Use: } \\
\text { Number of Registered } \\
\text { Initiatives 1997-2005 }\end{array}$ \\
\hline BW & 1976 & 16.7 & 14 & 1.19 & 1 \\
BY & 1949 & 10 & 14 & 0.71 & 12 \\
BE & 1997 & 10 & 60 & 0.17 & 4 \\
BB & 1993 & 3.8 & 120 & 0.03 & 9 \\
HB & 1962 & $10 / 20$ & 90 & 0.11 & 5 \\
HH & 1996 & 7.2 & 22.9 & 0.41 & 13 \\
HE & 1950 & 20 & 14 & 1.43 & 0 \\
MV & 1994 & 10 & $-\cdot$ & 0 & 4 \\
NI & 1994 & 10 & 180 & 0.06 & 5 \\
NW & 1950 & 14.7 & 32.7 & 0.86 & 1 \\
RP & 1948 & 13.2 & 44.7 & 0.59 & 2 \\
SL & 1982 & 20 & 14 & 1.43 & 5 \\
SN & 1993 & 12.7 & 240 & 0.05 & 2 \\
ST & 1994 & 11 & 180 & 0.06 & 6 \\
SH & 1995 & 5 & 180 & 0.03 & 2 \\
TH & 1994 & $8 / 10$ & $60 / 120$ & 0.13 & 5 \\
\hline
\end{tabular}

Notes:

Quorum as percentage of those entitled to vote in Land elections. Quorum, circulation time and mobilisation coefficient are average values (1997-2005). The investigation period starts with Berlin introducing the popular initiative in 1997. Absolute number of registered initiatives.

For Bremen, the first quorum $(10 \%)$ refers to statutory initiatives; the second $(20 \%)$ to constitutional initiatives.

In Thuringia, initiators can choose to collect signatures inside official locations (Sammlung in Amtsräumen, $8 \%$ in 60 days) or outside (freie Sammlung, 10\% in 120 days), e.g. on the streets or in shopping malls.

To obtain the Mobilisation coefficient, as calculated by Moser (1985), the quorum for each Land has to be divided by the corresponding circulation time. For Thuringia, the value was calculated using the requirements for collecting inside.

The Länder are abbreviated as follows: $B W=$ Baden-Württemberg, BY = Bavaria, $\mathrm{BE}=$ Berlin, $\mathrm{BB}=$ Brandenburg, $\mathrm{HB}=$ Bremen, $\mathrm{HH}=$ Hamburg, $\mathrm{HE}=$ Hesse, $\mathrm{MV}=$ Mecklenburg-West Pomerania, $\mathrm{NI}=$ Lower Saxony, $\mathrm{NW}=$ North Rhine-Westphalia, $\mathrm{RP}=$ RhinelandPalatinate, $\mathrm{SL}=$ Saarland, $\mathrm{SN}=$ Saxony, $\mathrm{ST}=$ Saxony-Anhalt, $\mathrm{SH}=$ Schleswig-Holstein, $\mathrm{TH}=$ Thuringia. 
highest quorums can be found in Hesse and Saarland, with both at 20 per cent. For Bremen, the first number (10 per cent) refers to statutory initiatives, the second to constitutional initiatives. In Thuringia, initiators can choose between collecting signatures inside official locations (Sammlung in Amtsräumen) or outside (freie Sammlung), e.g. on the streets or in shopping malls. The first number ( 8 per cent in 60 days) refers to signature gathering at official locations. Column four describes the circulation time in days. Only Mecklenburg-West Pomerania does not set a restriction, otherwise collectors are granted 14 to 240 days.

To account for the different requirements, column five shows the mobilisation coefficient (as calculated by Moser 1985) computed from the preceding two columns by dividing the quorum by circulation time. Larger mobilisation coefficient values correspond to higher hurdles the initiative must clear in order to qualify for a ballot vote. To calculate the coefficient for Bremen, the statutory initiative was used. For Thuringia, the qualifications for collecting signatures inside were incorporated. Not surprisingly, Mecklenburg-West Pomerania exhibits the lowest value. Other low values can be found in Brandenburg, Schleswig-Holstein and Saxony. Here, a comparatively high signature requirement is mediated by a rather long time frame in which they must be gathered. The same is true for Lower Saxony and Saxony-Anhalt. At the other end of the list, Hesse and Saarland stand out with high thresholds and short circulation time limits.

\section{Rules-in-Use: Initiative Frequency}

Between 1997 and 2005, 79 initiatives were officially registered in the Länder - in other words, they reached the circulation stage (see Table 1, column 6).

FIGURE 1

INITIATIVE FREQUENCY IN THE CIRCULATION STAGE PER YEAR (1997-2005)

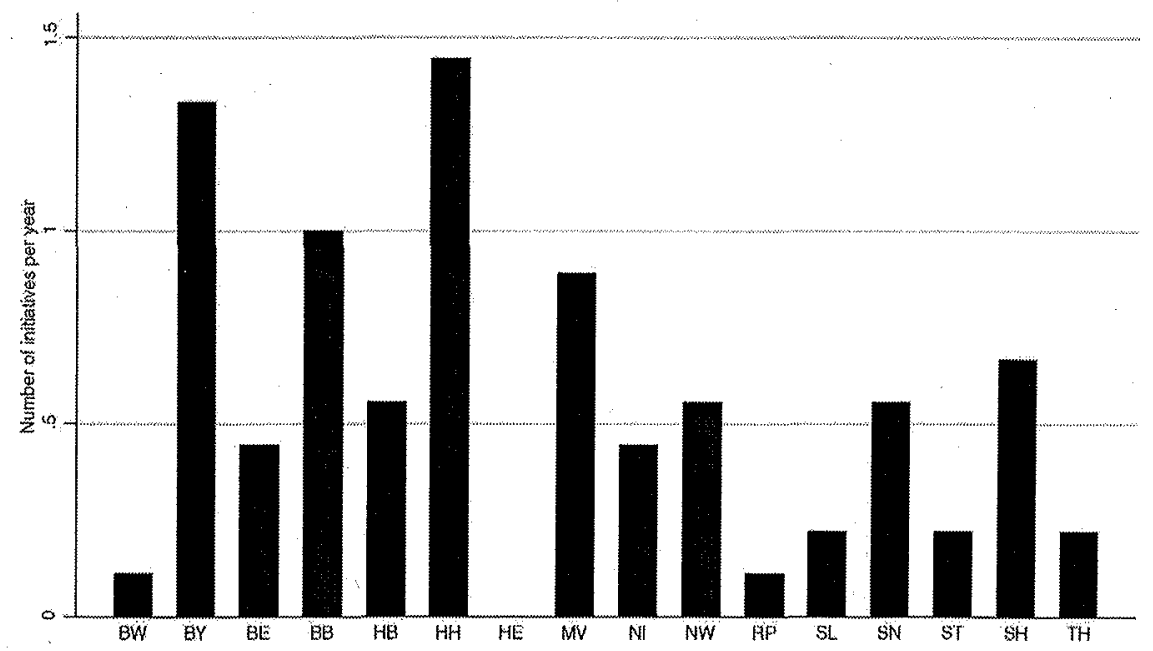


Hamburg accounts for 13 of these initiatives, despite the fact that this instrument was only introduced in the Hanseatic city in 1996. Bavaria is close behind with 12 initiatives. No initiatives have been registered in Hesse and only one in both Baden-Württemberg and Rhineland-Palatinate. For easier comparison, the number of initiatives is calculated per year. ${ }^{11}$ Figure 1 displays the relative frequency.

Hamburg ranks at the top with 1.44 initiatives per year, followed by Bavaria with 1.33. Exactly one initiative per year was proposed in Brandenburg and 0.89 in Mecklenburg-Western Pomerania. BadenWürttemberg and Rhineland-Palatinate, with 0.11 initiatives each, fall at the other end of the spectrum. Hesse comes last with zero procedures a year. The following section provides the theoretical background for the assumed relationship between institutional openness and initiative frequency.

\section{Theory and Hypothesis}

An analysis that enquires for the impact of configurations of political institutions in general, as well as for the consequences of direct democratic institutional requirements in particular, is rooted in the new institutionalist perspective.

During the 1980s; institutions returned to the focus of attention in different fields of political science in what was termed new institutionalism. In contrast to the old institutionalism, its successor regards institutions as both dependent and independent variables (Mayntz and Scharpf 1995: 43), thus rendering it possible to conduct an analysis like the one undertaken in this article. Where 'the classical institutionalism is merely concerned with the description of political institutions and their interrelationships', in new institutionalism, institutions 'are interpreted as structural incentives for political actions' shaping individual action (Kaiser 1997: 421f.). Whereas classical institutionalism focuses on formal rules, new institutionalism includes informal settings, thereby enabling the discovery of previously undetected effects (Kaiser 2002: 49).

There are, however, many branches of new institutionalism, as the importance of institutions was rediscovered in several research fields at roughly the same time (Goodin 1998; Kaiser 2002: 52ff.). Hall and Taylor (1996) list three different streams: historical, rational choice and sociological. Historical institutionalism defines institutions as 'the formal or informal procedures, routines, norms and conventions embedded in the organisational structure of the polity or economy' (Hall and Taylor 1996: 6). It emphasises the importance of path dependency in the development of institutions and their ability to mediate conflicts by setting and enforcing rules, norms and paradigms in human interactions (Hall and Taylor 1996: 5ff.; Sanders 2006: 39; Sørensen and Torfing 2007: 28). The rational choice approach focuses on the 'rules-of-the-game' set by institutions that determine a rational actor's strategies and the outcomes and pay-offs to 
be achieved (Hall and Taylor 1996: 10ff.; Sørensen and Torfing 2007: 28). Sociological institutionalism is sometimes described in opposition to the rational choice approach, as it not only highlights the importance of institutions as 'rules-of-the-game', but also the 'frames of meaning' influencing the actors (Hall and Taylor 1996: 14; Sørensen and Torfing 2007: 29). All differences aside, the three bodies understand institutions as 'elements of order and predictability' that facilitate cooperation and coordination (March and Olsen 2006: 4). Although each type sets its own emphasis, they converge on the fact that institutional arrangements ... are neither uniform nor unidirectional' (Weaver and Rockman 1993: 454) and that institutions matter and influence actions (Hall and Taylor 1996; Kaiser 1997, 1998, 2002; Lowndes and Wilson 2001; March and Olsen 1984). ${ }^{12}$

In this regard, direct democratic institutions can have a two-fold influence. First, their regulatory frameworks can impair governments. Depending on the characteristics of the direct democratic instrument in use, the course of action available to a government can vary considerably. Hug and Tsebelis (2002) show, for example, that giving people an unmediated say in the decision-making process, and thereby making them veto players, can have a substantial influence on governmental performance. Hug and Sciarini (2000) demonstrate in more detail how the provisions of a direct democratic institution can influence all actors involved and the choice people make at the ballot boxes. To determine the impact of different direct democratic instruments on political actors and their decisions, numerous studies aim to classify them according to criteria like the right of initiation, majority requirements, and validity of the results (cf. Setälä 1999, 2006; Smith 1976; Suksi 1993; Vatter 2000). Second, the regulations can also affect potential initiators. This is particularly true for the popular initiative, where institutional settings directly determine the costs of its launch (Barankay et al. 2003) and realisation. These costs can include the amount of time and money needed to initiate the process, advertise the matter and rally the necessary support, as well as transaction costs. The assumption is that the higher the requirements, the higher the total costs for the initiators. In particular, rational choice institutionalism claims that institutions as rules-of-thegame 'tend to determine the actual range of choices and options of the actors; the pay-offs of the different options, or combinations of options; the available information about options, costs and benefits' (Sørensen and Torfing 2007: 28). The rational actor is able to weigh costs and benefits of the actions before choosing one. Higher costs of launching an initiative should therefore lower the incentive to do so. In other words, we expect to find fewer initiatives where legal requirements are harder to meet. Based on this line of reasoning, we formulate the main hypothesis:

Hypothesis: The higher the institutional openness, the higher the use of popular initiatives. 
Referring to the literature on direct democracy, there are some publications that have already tested this relationship. However, research designs and findings differ widely. In a rather descriptive way, Rehmet (2002: 108) argues that high signature requirements can explain the comparatively low use of the popular initiative in some of the German Länder. ${ }^{13} \mathrm{He}$ underpins this claim with data on initiatives from 1946 to 2001. Kampwirth (2003) uses a similar approach to come to the conclusion that high thresholds are responsible for low initiative frequency. For Weixner (2002: 222), a high signature requirement is one important factor in explaining the infrequency of initiative use in certain Länder. However, she does not use empirical tests to support her argument. Although there is fragmented evidence that institutional requirements may have an effect on initiative frequency in the German Länder, to date systematic tests are mostly lacking. ${ }^{14}$

In his description of direct democratic institutions in the US states, Magleby (1994: 225) writes that the 'stringency of a state's signature threshold is inversely related to the frequency of measures qualifying for the ballot'. Matsusaka (1995) utilises the institutional settings as an independent variable to calculate the effect of the initiative on public finances and tax rates. He argues that as 'the signature requirement rises, it becomes increasingly difficult to use the initiative' and determines that it is well suited as an indicator for 'ease of use of the initiative' (Matsusaka 1995: 59lf.). Banducci (1998: 116) runs a multiple analysis of initiative use in 23 states between 1962 and 1990, finding that as the difficulty of qualifying an initiative for the ballot increases, the number of initiatives actually on the ballot is predicted to decrease'.

Nevertheless, some contributions question the influence of institutional settings on initiation frequency. Barankay et al. (2003: 173f.), for example, list several arguments for why the null hypothesis stating that there is no impact could be plausible. (1) While institutional requirements do influence the variable costs of launching an initiative, they do not necessarily determine the fixed costs, which arguably may comprise a larger fraction of the total costs. Lower hurdles thus need not lead to more initiatives. (2) Lower costs of entry offer new actors the possibility to launch an initiative, possibly resulting in more initiatives competing for attention and decreasing chances of success. (3) The possibility of more initiatives being launched due to lower hurdles may make the legislature more responsive to the public's demands and may thereby result in decreased frequency. (4) The saliency of an issue may be more important to the voters and more pivotal for success than the costs of launching. Consequently, institutional settings may not be sufficient to explain the frequency of initiatives. Barankay et al. (2003) then analyse different direct democratic institutions in 21 Swiss cantons during the period 1970 to 1996. After running a series of regressions, they come to the conclusion that 'institutional openness has hardly any impact on the use of direct democratic institutions' (Barankay et al. 2003: 183). The results obtained by Vatter (2002) support these findings. His studies of direct 
democracy in the Swiss cantons between 1980 and the late 1990s reveal that institutional hurdles do not matter. Trechsel (2000) investigates the same period as Barankay et al. (2003) and arrives at the same conclusion. However, he discovers that lowering institutional hurdles can have a positive influence on initiative use in the cantons.

As both the main and the null hypotheses can be justified, further empirical investigation is needed.

\section{Research Design}

In this section, initiative frequency per year is used as the dependent variable to test the main hypothesis presented above. The focus is on initiatives in the circulation stage and thus on initiatives that successfully cleared the initiation stage and are therefore officially registered with the Land authorities. A prominent attempt to measure the height of institutional hurdles is the mobilisation coefficient by Moser (1985), as presented above in the first section. Alternatively, one could separately examine signature requirements and circulation time. Here, all three approaches are used as independent variables to determine the influence of institutional settings on the frequency of popular initiatives. The research period covers nine years, starting with Berlin's introduction of the popular initiative in 1997 and ending in 2005.

The analysis is conducted in three steps. First, three bivariate correlations are calculated to determine the institutional indicator that best explains the variance in the relative number of initiatives introduced per year. Second, multiple cross-sectional OLS regressions are run to test the indicator's influence on relative initiative frequency by incorporating several political, cultural and socio-economic control variables into the models. The rationale for including these factors is as follows: 'even where institutional arrangements do contribute to overall differences in specific capabilities, moreover, these effects usually are strongly mediated by other institutional and noninstitutional factors' (Weaver and Rockman 1993: 446; for a similar argument see Scharpf 1989). Kaiser (1997: 422) argues that we must also 'consider these contextual factors as intervening variables which enlarge or diminish the range of alternatives which political actors think are available in decision-making situations'. A list of control factors can be found in Table 2.

The control factors are assigned to three groups - political, cultural and socio-economic - and are derived from the international literature on direct democracy as the most relevant (e.g. Fijalkowski 1993; Luthardt 1994; Tolbert/Smith 2006; Vatter 2002). A more detailed description of all factors, as well as their operationalisation and related hypotheses can be found in the Appendix. Nevertheless, an overview of the main arguments is presented in the following.

The effective number of parties by Laakso and Taagepera (1979) indicates the fragmentation of the party system. In accordance with the findings of 
TABLE 2

CONTROL FACTORS AND EXPECTED INFLUENCE

\begin{tabular}{lcc}
\hline Factor & Expected Influence \\
\hline Political factors & + \\
Effective number of parties & + \\
Percentage of the vote share for left parties & - \\
Percentage of the vote share for parties in government & - \\
Number of parties in government & $+/-$ \\
Turnout in Land parliament elections & $+/-$ \\
Cultural factors & $+/-$ \\
Percentage of party members & $+/-$ \\
Percentage of employees with union membership & $+/-$ \\
Percentage of population doing voluntary work & + \\
Percentage of citizens working in an action committee & + \\
Socio-economic factors & + \\
Total Land population & + \\
Percentage of population in cities with more than 20,000 inhabitants & + \\
Percentage of employees in third sector &
\end{tabular}

Notes: See the Appendix for more information on factors and hypotheses, $+=$ positive expected influence on relative number of initiatives; $-=$ negative expected infuence on initiative frequency.

Ladner and Brändle (1999) on Swiss cantons, it is assumed that a larger number of parties in parliament leads to more initiatives as small parties use the instruments to gain additional influence on the decision-making process. Moreover, Luthardt (1994: 95) argues that in particular green and left-wing parties favour direct democratic institutions as these parties value participatory democracy due to their basic democratic roots. The vote share for the German left-wing parties - SPD, Bündnis 90/Die Grünen, PDS and $\mathrm{SSW}^{15}$ - is therefore taken into account, assuming that their political clout has a positive impact on initiative use. The percentage of vote share for the parties in government and the number of parties in government both indicate that a broader spectrum of interests is included in the political decision-making process, lessening the need to launch citizen initiatives (Vatter 2000: 178). Whether high voter turnout in elections bolsters or hinders direct democracy is still a matter of debate (cf. Budge 2006; Tolbert and Smith 2006). While some argue that too many decisions at the ballot box could lead to 'voting fatigue' resulting in lower turnouts, others claim that direct democracy could intensify public interest in political decisions, thereby enhancing participation. The cultural factors hearken back to research on direct democracy and social capital (e.g. Freitag 2006). Whether membership in clubs, parties, voluntary organisations and unions increases or decreases the use of the popular initiative has yet to be definitively answered. One line of reasoning is that these organisations bring people with similar opinions together and provide the structures necessary to start an initiative and then rally support for it. The opposite line states that these organisations suffice as a way of voicing opinions such that direct 
democratic institutions are no longer necessary. Finally, according to Fijalkowski (1993), the number of initiatives should increase in more individualised, modernised and urban societies. Modernisation, urbanisation and individualisation should lead to more heterogeneous interests, which cannot all be incorporated into the political decision-making process, enhancing the incentive to use direct democratic instruments to further individual interests. The factors are measured using information on total Land population, percentage of population living in cities with more than 20,000 inhabitants, and percentage of employees in the third sector. Third, as a last analytical step, several tests are conducted to ensure the robustness and validity of the results.

\section{Empirical Findings}

This section analyses the impact of direct democratic rules-in-form on rulesin-use in the German Länder. The hypothesis to be tested states that higher institutional requirements correspond to lower annual numbers of initiatives. In bivariate correlations between the three different measures of institutional influence (quorum and circulation time in the circulation stage and resulting mobilisation coefficient) and the use of the popular initiative, one finds that the indicator that best explains the variance appears to be the quorum in the circulation stage (Table 3).

For two of the three indicators, quorum and mobilisation coefficient, the signs correspond to the hypothesised direction. While the circulation quorum apparently has a relatively strong negative influence on initiative use, mobilisation coefficient and circulation time show insignificant results. For the remainder of this article, the quorum in the circulation stage is used as the main indicator of institutional impact, while circulation time and mobilisation coefficient are only used as by-products.

Figure 2 displays a scatterplot between initiative use and the quorum of the circulation stage. The straight line represents a regression line of fitted values with a negative slope, as indicated by the Pearson coefficient of -0.61 in column two of Table 3. The regression line's position seems to be considerably influenced by Hamburg and Bavaria, which are located

TABLE 3

INSTITUTIONAL DETERMINANTS (CIRCULATION STAGE)

\begin{tabular}{lccc}
\hline & Quorum & Circulation Time & Mobilisation Coefficient \\
\hline Pearson's coefficient & $-0.61^{* *}$ & -0.01 & -0.35 \\
Level of significance & 0.01 & 0.98 & 0.19 \\
\hline
\end{tabular}

Notes: Dependent variable = relative number of initiatives initiated in the circulation stage per year; Bivariate Pearson correlation; Number of cases $=16$; Time period $=1997-2005$. For Bremen information on statutory initiatives were used, for Thuringia it was assumed that signatures were gathered inside (refer to Table 1). 
FIGURE 2

INITIATIVE USE AND QUORUM OF THE CIRCULATION STAGE

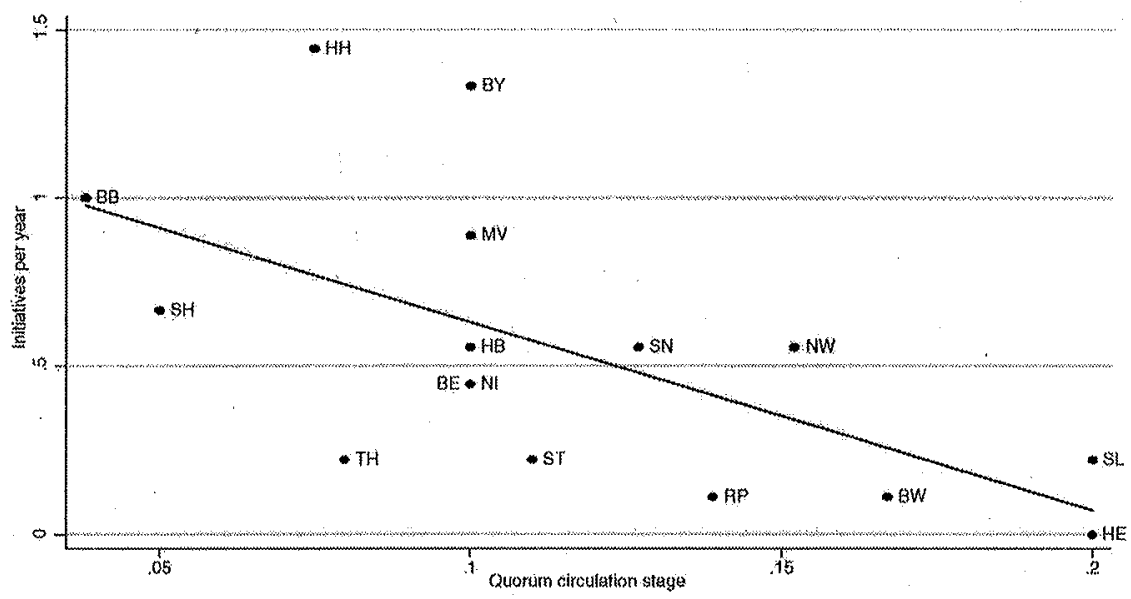

comparatively far away from it, as well as by Hesse and Saarland, which are located in the lower right-hand corner. ${ }^{16}$ Excluding these Länder from the calculation does not significantly change the results. Without Bavaria and Hamburg, both the level of significance and the model fit increase while the coefficient and sign remain constant.

Table 4 displays the results of the multiple OLS regressions. ${ }^{17}$ The calculations estimate the influence of the institutional settings (the quorum in the circulation stage) on initiative frequency while controlling for several other factors. These were assigned to the different models according to thematic relations. Attention was paid to not exceeding the total number of four variables per model. ${ }^{18}$ In each of the five models, the circulation quorum emerges as the only significant indicator. Although the parameter varies, the direction of its sign remains constant. This indicates that for the German Länder, higher signature requirements negatively influence the frequency of initiatives. At first glance, these results seem to support the main hypothesis.

After estimating the models, correlations between the respective control variables were conducted to check for multicollinearity (Jann 2006), which was detected in models 1 and 5 . The affected variables were then excluded one by one from the analyses; however, the results were not substantially altered. Variance Inflation Factor (VIF) tests confirm these findings. Consequently, multicollinearity does not seem to be an issue here.

Subsequently, a Breusch-Pagan/Cook-Weisberg test for heteroscedasticity was performed and tested positively in model $1 .{ }^{19}$ To control for the presence of heteroscedasticity, robust $\mathrm{HC} 3$ standard errors were included in all models. ${ }^{20}$ Again, neither the sign nor the level of significance of the 
TABLE 4

DETERMINANTS OF INITIATIVE USE IN THE CIRCULATION STAGE

\begin{tabular}{|c|c|c|c|c|c|}
\hline Variables/Models & Model 1 & Model 2 & Model 3 & Model 4 & Model 5 \\
\hline Quorum of circulation stage & $\begin{array}{l}-6.10^{* *} \\
(2.56)\end{array}$ & $\begin{array}{l}-5.51^{* *} \\
(2.22)\end{array}$ & $\begin{array}{l}-6.56^{* *} \\
(2.24)\end{array}$ & $\begin{array}{l}-59.84^{* *} \\
(22.56)\end{array}$ & $\begin{array}{r}-5.49^{*} \\
(2.71)\end{array}$ \\
\hline Effective number of parties & $\begin{array}{c}-0.28 \\
(0.20)\end{array}$ & & & & \\
\hline Left party vote share & $\begin{array}{r}-0.08 \\
(1.29)\end{array}$ & & & & \\
\hline Governmental vote share & & $\begin{array}{c}0.90 \\
(1.62)\end{array}$ & & & \\
\hline Number of government parties & & $\begin{array}{r}-0.14 \\
(0.39)\end{array}$ & & & \\
\hline Turnout & & $\begin{array}{l}1.26 \\
(1.67)\end{array}$ & & & \\
\hline Party members & & & $\begin{array}{c}7.12 \\
(11.26)\end{array}$ & & i \\
\hline Union members & & & $\begin{array}{r}-4.19 \\
(7.87)\end{array}$ & & \\
\hline Citizens action committees & & & & $\begin{array}{r}-135.67 \\
(145.01)\end{array}$ & \\
\hline Volunteers & & & & $\begin{array}{c}17.40 \\
(39.42)\end{array}$ & \\
\hline Population & & & & & $\begin{array}{c}0.00 \\
(0.00)\end{array}$ \\
\hline Urban 20 & & & & & $\begin{array}{r}-0.20 \\
(0.59)\end{array}$ \\
\hline Third sector employees & & & & & $\begin{array}{c}2.96 \\
(3.27)\end{array}$ \\
\hline Constant & $\begin{array}{c}1.99 \\
(1.36)\end{array}$ & $\begin{array}{l}0.12 \\
(1.28)\end{array}$ & $\begin{array}{r}1.54^{*} \\
(0.81)\end{array}$ & $\begin{array}{l}14.34^{* *} \\
(6.58)\end{array}$ & $\begin{array}{c}0.97 \\
(2.23)\end{array}$ \\
\hline$N$ & 16 & 16 & 16 & 16 & 16 \\
\hline $\mathrm{R}^{2}$ & 0.45 & 0.42 & 0.40 & 0.45 & 0.49 \\
\hline Mean VIF & 1.39 & 1.12 & 1.49 & 1.25 & 2.10 \\
\hline
\end{tabular}

Notes: Cross-sectional OLS regression. Non-standardised regression coeficients. Values in brackets represent robust $\mathrm{HC} 3$ standard errors. Dependent variable $=$ relative number of initiatives initiated per year. Significance using robust HC3 standard errors: ${ }^{* * *} \mathrm{p}<0.01$; ${ }^{* *} \mathrm{p}<0.05 ;{ }^{*} \mathrm{p}<0.1$. For description of indicators see Table 2 and Appendix A. Time period $=1997-2005$. The control factors were assigned to the models according to thematic relation.

institutional indicator changed considerably, only the parameter varied. Heteroscedasticity thus does not seem to influence the results.

To detect influential cases, Cook's D can be used to determine the leverage of each Land on the outcome. Table 5 reports Länder that are located above the threshold of $4 / n=0.25 .^{21}$ All models, except for the third, show Bavaria and/or Hamburg as influential cases. This comes as little surprise, as they were already identified as outliers in the bivariate correlations: they feature the highest number of initiatives initiated per year but do not account for the lowest quorum. Model 5 additionally points to Saarland, which, due to its comparatively high quorum of 20 per cent, was also previously detected as influential case. All models were computed 
TABLE 5

LEVERAGE (COOKS D)

\begin{tabular}{lccccc}
\hline & Model 1 & Model 2 & Model 3 & Model 4 & Model 5 \\
\hline $\mathrm{D}>4 / \mathrm{n}$ & BY & BY, HH & - & HH & BY, HH, SL \\
\hline $\mathrm{N}=16$. & & & & & \\
\end{tabular}

excluding these cases one by one or in combination; once again, the results did not significantly change.

In a final step, all control factors were randomly assigned to the models. Using only one control factor, the quorum still emerged as the only significant variable, the sign being negative. The same holds true when two control factors are incorporated.

To further support our results, we randomly assigned one or two control factors to the other two institutional variables, circulation time and mobilisation coefficient. Regardless of the combinations, none of the two indicators turns out to be significant. Their signs, however, always point in the assumed direction and confirm the findings obtained in the bivariate analyses.

In sum, the present results seem to support the hypothesis that institutional requirements, namely, the number of required signatures, influence the use of the initiative in the German Länder in the period between 1997 and 2005. Other factors appear to be of minor importance. All tests further indicate that the results can be considered robust. ${ }^{22}$

\section{Conclusion}

Since Reunification, direct democratic instruments have garnered increased attention in the German Länder, which in turn is reflected by the growing number of publications devoted to this matter. The focus of attention is most often on the popular initiative that enables voters to directly influence the political decision-making process.

As there is an ongoing and controversial debate about the relevance of institutional settings for the use of direct democratic instruments (Banducci 1998; Barankay et al. 2003; Magleby 1994; Matsusaka 2005; Trechsel 2000; Vatter 2000,2002), the aim of this article has been to answer the question of whether institutions matter for initiative use in the German Länder. The emphasis was on the circulation stage and its requirements regarding number of signatures to be collected, the time granted to do so and the mobilisation coefficient derived from them. Bivariate correlations between each of the three institutional factors and the relative frequency of initiatives showed that the quorum best explains the differences across the Länder. In order to test this relationship empirically, several regression models incorporating a number of political, cultural and socio-economic factors were computed. The result, however, did not change: the quorum in the 
TABLE 6

COMPARISON OF INSTITUTIONAL REQUIREMENTS IN THE CIRCULATION STAGE IN THE GERMAN LÄNDER, THE SWISS CANTONS AND THE US STATES

\begin{tabular}{|c|c|c|c|c|c|c|c|c|c|}
\hline & \multicolumn{3}{|c|}{ Quorum (in \%) } & \multicolumn{3}{|c|}{ Circulation Time (Days) } & \multicolumn{3}{|c|}{ Mobilisation Coefficient } \\
\hline & Lowest & Highest & $\varnothing$ & Lowest & Highest & $\varnothing$ & Lowest & Highest & $\varnothing$ \\
\hline $\mathrm{D}$ & 3.8 & 20 & 10.8 & 14 & none & 85.2 & 0 & 1.4 & 0.4 \\
\hline $\mathrm{CH}$ & 0 & 5.7 & 2.2 & 60 & 540 & 327 & 0 & 0.06 & 0.015 \\
\hline USA & 2 & 15 & 7.2 & 64 & none & 325.5 & 0 & 0.09 & 0.02 \\
\hline
\end{tabular}

Notes: For all subnational entities, requirements for the (direct) statutory initiative were used Information on Germany and Switzerland derived from Magin and Eder (2007: 181). Own research was conducted for the USA. All institutional requirements as of 2006.

circulation stage always emerged as the only significant variable able to account for relative initiative frequency. For the research period 1997 to 2005 , the rules-in-form, represented by the circulation quorum, thus seem to impair the rules-in-use; the empirical findings appear to support the main hypothesis that institutional openness matters.

At first glance, these results seem contradictory to the existing research, in particular to studies on the Swiss cantons (e.g. Barankay et al. 2003 or Vatter 2002) that find no relation between institutional openness and the number of initiatives. For the US states, however, there is research to support this claim (cf. Magleby 1994). We can conclude that institutional settings $d o$ have an impact, but only if they reach a certain threshold. A comparison of the institutional requirements in the Swiss cantons and the US states to those in the German Länder (Table 6) reveals the following picture. While the cantons show the lowest quorum requirements, the Länder feature the highest hurdles and the US states are somewhere between the two, albeit closer to the Germans. The mean values for the US states' and Swiss cantons' circulation times are quite similar; the German Länder, however, grant on average considerably less time to collect the required signatures. The same is true for the mobilisation coefficient: the states bear resemblance to the cantons, with the latter displaying slightly lower values. The Länder are far behind. It seems safe to conclude that empirical studies on the Swiss cantons do not find institutional openness to affect initiative frequency, simply because the relatively low requirements do not present a real obstacle to potential initiators. In the US states, and in particular in the German Länder, the picture looks quite different, as requirements are (much) higher and therefore have a stronger impact on initiative use. With this in mind, institutional settings can be viewed as adjustment screws, whose loosening or tightening exerts an influence on initiative frequency.

\section{Acknowledgements}

This article was written as part of a research project on patterns of democracy in the German Länder which was founded by the German 
Research Foundation. We would like to thank the anonymous reviewers and the editor for their comments on previous drafts.

\section{Notes}

1. The states are the Republic of Bosnia and Herzegovina, Serbia, and the Czech Republic.

2. There is a conceptual blur when it comes to instruments of citizen-initiated institutions and their classifications. One has to pay attention to the fact that the English term 'popular initiative' translates into 'Volksgesetzgebung' in the German Länder but to 'Volksinitiative' in the Swiss cantons. The German 'Volksinitiative' is, however, either part of the Volksgesetzgebung's initiation stage or a separate instrument initiated by the voters to address the Land parliament. The parliament is then free to decide on the matter; however, a ballot vote is not provided (Eder and Magin 2008a: 364f .)

3. For patterns of the Länder democracies, refer to Freitag and Vatter (2008).

4. See Rothstein (1996: 146) for a definition of the terms rules-in-form and rules-in-use.

5. There are only two exceptions allowing for direct democratic decisions on the national level: First, Art. 29 regulates the use of a ballot vote when the alteration of Land borders is in question. Second, Art. 146 provides for the possibility of a referendum when a new national constitution is up for approval (Schmidt 2000: 356).

6. Here, West Berlin is excluded due to the special status associated with being under Allied supervision.

7. A political scandal that took place prior to the Landtag elections in Schleswig-Holstein in 1987. Björn Engholm, the SPD candidate for Land prime minister, was spied on by a journalist authorised by then prime minister Uwe Barschel (CDU). Some weeks after the public learned about the affair, Barschel was found dead in a Swiss hotel room. Up until now, the circumstances of his death remain unsettled.

8. Bavaria was the only Land to have a Senate (Wiegand 2006: 409ff.).

9. The use of the popular initiative to further direct democracy at the Land and/or municipal level is quite common. Initiatives on this issue can be found in almost all Länder after 1990.

10. Mecklenburg-Western Pomerania, for example, does not have an initiation stage at all. For a detailed description of the initiation stage in all Länder, refer to Magin and Eder (2007).

11. The relative frequency was chosen to standardise the indicator. As Table 1 shows, some Länder introduced the popular initiative as late as 1996 or 1997, possibly leading to a biased absolute frequency with regard to 'start-up effects': voters must first acquaint themselves with the new instrument, possibly resulting in rather infrequent use during the first year(s). Moreover, further analyses not shown here reveal that the findings do not change if we use the absolute frequency as the indicator of the dependent variable.

12. The three bodies differ in how they define institutions in detail, the methodology they use (DiMaggio and Powell 1991: 7f; Immergut 1998: 5), and they do not agree on exactly how institutions shape actors' preferences (Rothstein 1996: 147ff.). For detailed descriptions of the bodies see Hall and Taylor (1996), Rhodes et al. (2006) and Sørensen and Torfing (2007).

13. These Länder are Baden-Württemberg, Bremen, Hesse, Rhineland-Palatinate and Saarland. Additionally, he observes high initiative frequencies in Brandenburg, Hamburg, Mecklenburg-West Pomerania and Schleswig-Holstein where requirements are comparatively low (Rehmet 2002: 108)

14. Eder and Magin $(2008 a, b)$ develop on additive index measuring instiutional openness. Their results hint at a relation between the legal regulations and initiative use in the German Länder between 1990 and 2005.

15. SPD - Sozialdemokratische Partei Deutschlands, PDS - Partei des demokratischen Sozialismus, SSW - Südschleswigscher Wählerverband. For the classification of parties see Shikano and Becker (2004). 
16. A leverage-versus-squared residuals plot confirms these results.

17. Cross-sectional OLS regressions were deliberately chosen as the independent variable is invariant over time in most Länder, which speaks against using a pooled cross-sectional time series analysis (Kittel 1999: 245). Additionally, as the number of cases is rather low, we wanted to keep the model as simple as possible to ensure interpretable results.

18. Wagschal (1999: 225) suggests leaving at least 10 degrees of freedom for the residuals in order to obtain as robust results as possible. As $\mathrm{N}=16$, no more than four independent variables are included in a model to meet this requirement.

19. Residual vs. fitted-plot were drawn to support the findings.

20. Arguments in favour of using $\mathrm{HC} 3$, especially when $\mathrm{N}$ is small, can be found in Long and Ervin (2000).

21. The threshold of 4/n is suggested by Kohler and Kreuter (2006: 227) and Schnell (1994: 224)

22. In addition, it should be noted that the reported findings are not sensitive to the inclusion of other controlling factors such as number of government changes, local direct democracy, degree of decentralisation, percentage of population attending church/religious service, percentage of Catholics, annual change in GDP per capita and unemployment rate.

\section{References}

Banducci, Susan A. (1998). 'Direct Legislation. When Is It Used and When Does It Pass?', in Shaun Bowler, Todd Donovan and Caroline J. Tolbert (eds.), Citizens as Legislators. Direct Democracy in the United States. Columbus: Ohio State University Press, 109-31.

Barankay, Iwan, Pascal Sciarini, and Alexander Trechsel (2003). 'Institutional Openness and the Use of Referendums and Popular Initiatives. Evidence from Swiss Cantons', Swiss Political Science Review, 9:1, 169-99.

Budge, Ian (2006). 'Direct and Representative Democracy: Are They Necessarily Opposed?', Representation, 42:1, 1-12.

Cronin, Thomas E. (1989). Direct Democracy. The Politics of Initiative, Referendum and Recall. Cambridge, MA: Harvard University Press.

DiMaggio, Paul J, and Walter W. Powell (1991). 'Introduction', in Walter W. Powell and Paul J. DiMaggio (eds.), The New Institutionalism in Organizational Analysis. Chicago: University of Chicago Press, 1-38.

Eder, Christina, and Raphael Magin (2008a). 'Volksgesetzgebung in den deutschen Bundesländern. Ein Vorschlag zu ihrer empirischen Erfassung aus subnational-vergleichender Perspektive', Zeitschrift fiir Parlamentsfragen, 39:2, 358-78.

Eder, Christina, and Raphael Magin (2008b). 'Direkte Demokratie', in Markus Freitag and Adrian Vatter (eds.), Die Demokratien der deutschen Bundesländer. Politische Institutionen im Vergleich. Opladen: Verlag Barbara Budrich, 257-308.

Fijalkowski, Jürgen (1993). 'Erfahrungen mit Volksabstimmungen zu Sachfragen - Erfordernisse und Ergebnisse kategorialer Differenzierung', in Hans-Dieter Klingemann and Wolfgang Luthardt (eds.), Wohlfahrtsstaat, Sozialstruktur und Verfassungsanalyse. Opladen: Westdeutscher Verlag, 147-67.

Fossedal, Gregory A. (2002). Direct Democracy in Switzerland. New Brunswick, NJ: Transaction Publishers.

Freitag, Markus (2006). 'Bowling the State Back in. Political Institutions and the Creation of Social Capital', European Journal of Political Research, 45:1, 123-52.

Freitag, Markus, and Adrian Vatter (2004). 'Political Institutions and the Wealth of Regions. Swiss Cantons in a Comparative Perspective', European Urban and Regional Studies, 11:4, 291-301.

Freitag, Markus, and Adrian Vatter, eds. (2008). Die Demokratien der deutschen Bundesländer. Politische Institutionen im Vergleich. Opladen: Verlag Barbara Budrich.

Goodin, Robert E. (1998). 'Institutions and Their Design', in Robert E. Goodin (ed.), The Theory of Institutional Design. Cambridge: Cambridge University Press, 1-53. 
Hall, Peter A., and Rosemary C.R. Taylor (1996). Political Science and the Three New Institutionalisms. Köln: Max-Planck-Institut für Gesellschaftsforschung.

Hernekamp, Karl (1979). Formen und Verfahren direkter Demokratie. Dargestellt anhand ihrer Rechtsgrundlagen in der Schweiz und in Deutschland. Frankfurt a.M.: Metzner.

Heußner, Hermann K. (1994). Volksgesetzgebung in den USA und in Deutschland. Ein Vergleich der Normen, Funktionen, Probleme und Erfahrungen. Köln: Carl Heymanns.

Hug, Simon, and Pascal Sciarini (2000). 'Referendums on European Integration. Do Institutions Matter in the Voter's Decision?', Comparative Political Studies, 33:1, 3-36.

Hug, Simon, and George Tsebelis (2002). 'Veto Players and Referendums Around the World', Journal of Theoretical Politics, 14:4, 465-515.

Immergut, Ellen (1998). 'The Theoretical Core of the New Institutionalism', Politics and Society, 26:1, 5-34.

Jann, Ben (2006). 'Diagnostik von Regressionsschätzungen bei kleinen Stichproben', Kölner Zeitschrift fïr Soziologie und Sozialpsychologie, Sonderheft 44, 421-52.

Kaiser, André (1997). 'Types of Democracy. From Classical to New Institutionalism', Journal of Theoretical Politics, 9:4, 419-44.

Kaiser, André (1998). 'Vetopunkte der Demokratie. Eine Kritik neuerer Ansätze der Demokratietypologie und ein Alternativvorschlag', Zeitschrift für Parlamentsfragen, 29:3, $525-41$.

Kaiser, André (2002). Mehrheitsdemokratie und Institutionenreform. Verfassungspolitischer Wandel in Australien, Grossbritannien, Kanada und Neuseeland im Vergleich. Frankfurt: Campus Verlag.

Kampwirth, Ralph (2003). 'Der ernüchterte Souverän. Bilanz und Perspektiven der direkten Demokratie in den 16 Bundesiändern und auf Bundesebene', Zeitschrift für Parlamentsfragen, $34: 4,657-71$.

Kirchgässner, Gebhard, Lars P. Feld, and Marcel Savioz (1999). Die direkte Demokratie. Modern, erfolgreich, entwicklungs- und exportfähig. Basel, Genf, and München: Helbing und Lichtenhahn.

Kittel, Bernhard (1999). 'Sense and Sensitivity in Pooled Analysis of Political Data', European Journal of Political Research, 35:2, 225 -53.

Kohler, Ulrich, and Frauke Kreuter (2006). Datenanalyse mit Stata. Allgemeine Konzepte der Datenanalyse und ihre praktische Anwendung. München: Oldenbourg Veriag.

Kost Andreas, ed. (2005). Direkte Demokratie in den deutschen Ländern. Eine Einführung. Wiesbaden: VS Verlag für Sozialwissenschaften.

Laakso, Markku, and Rein Taagepera (1979). "'Effective" Number of Parties. A Measure with Application to West Europe', Comparative Political Studies, 12:1, 3-27.

Ladner, Andreas, and Michael Brändle (1999). 'Does Direct Democracy Matter for Political Parties? An Empirical Test in the Swiss Cantons', Party Politics, 5:3, 283302.

Long, J. Scott, and Laurie H. Ervin (2000). 'Using Heteroscedasticity Consistent Standard Errors in the Linear Regression Model', The American Statistician, 54:3, 217-24.

Lowndes, Vivien, and David Wilson (2001). 'Social Capital and Local Governance. Exploring the Institutional Design Variable', Political Studies, 49:4, 629-47.

Luthardt, Wolfgang (1994). Direkte Demokratie. Ein Vergleich in Westeuropa. Baden-Baden: Nomos.

Magin, Raphael, and Christina Eder (2007). 'Direkte Demokratie in den Bundesländern: Grundlagen, Institutionen, Anwendungen', in Markus Freitag and Uwe Wagschal (eds.), Direkte Demokratie. Bestandsaufnahmen und Wirkungen im internationalen Vergleich. Münster: LIT Verlag, 151-87.

Magleby, David B. (1994). 'Direct Legisiation in the American States', in David Butler and Austin Ranney (eds.) Referendums Around the World: The Growing Use of Direct Democracy. Washington, DC: AEI Press, 218-57.

March, James G., and Johan P. Olsen (1984). 'The New Institutionalism. Organizational Factors in Political Life', American Political Science Review, 78:3, 734-49. 
March, James G., and Johan P. Olsen (2006). 'Elaborating the "New Institutionalism"', in R.A.W. Rhodes, Sarah A. Binder and Bert A. Rockman (eds.), The Oxford Handbook of Political Institutions. Oxford: Oxford University Press, 3-21.

Matsusaka, John G. (1995). 'Fiscal Effects on Voter Initiatives. Evidence From the Last 30 Years', Journal of Political Economy, 103:3, 587-623.

Matsusaka, John G. (2004). For the Many or the Few. The Initiative, Public Policy, and American Democracy. Chicago: University of Chicago Press.

Matsusaka, John G. (2005). 'The Eclipse of Legislatures: Direct Democracy in the 21st Century', Public Choice, 124:1/2, 155-77.

Mayntz, Renate, and Fritz W. Scharpf (1995). 'Der Ansatz des akteurszentrierten Institutionalismus', in Renate Mayntz Fritz W. Scharpf (eds.), Gesellschaftliche Selbstregelung und politische Steuerung. Frankfurt: Campus Verlag, 39-72.

Mielke, Siegfried, and Ernst Reutter, eds. (2004). Länderparlamentarismus in Deutschland. Wiesbaden: VS Verlag für Sozialwissenschaften.

Möckli, Silvano (2007). 'Direkte Demokratie in den Gliedstaaten der USA', in Markus Freitag, and Uwe Wagschal (eds.), Direkte Demokratie. Bestandsaufnahmen und Wirkungen im internationalen Vergleich. Münster: LIT Verlag, 19-40.

Moser, Christian (1985). Institutionen und Verfahren der Rechtsetzung in den Kantonen. Bern: Forschungszentrum für Schweizerische Politik.

Niedermayer, Oskar (2005). Parteimitglieder seit 1990: Version I/2005, available at http:// www.polwiss.fu-berlin.de/osz/dokumente/PDF/mitglied.pdf (accessed 22 June 2006).

Rehmet, Frank (2002). 'Direkte Demokratie in den deutschen Bundesländern', in Theo Schiller and Volker Mittendorf (eds.), Direkte Demokratie. Forschung und Perspektiven. Wiesbaden: Westdeutscher Verlag, 102-14.

Rhodes, R.A.W., Sarah A. Binder, and Bert A. Rockman, eds. (2006). The Oxford Handbook of Political Institutions. Oxford: Oxford University Press.

Rothstein, Bo (1996). 'Political Institutions. An Overview', in Robert E. Goodin and HansDieter Klingemann (eds.), A New Handbook of Political Science. Oxford: Oxford University Press, 133-66.

Rux, Johannes (2008). Direkte Demokratie in Deutschland: Rechtsgrundlagen und Rechtswirklichkeit der unmittelbaren Demokratie in der Bundesrepublik Deutschland und ihren Ländern. Baden-Baden: Nomos.

Sanders, Elizabeth (2006). 'Historical Institutionalism', in R.A.W. Rhodes, Sarah A. Binder and Bert A. Rockman (eds.), The Oxford Handbook of Political Institutions. Oxford: Oxford University Press, 39-55.

Scharpf, Fritz W. (1989). 'Decision Rules, Decision Styles and Policy Choices', Journal of Theoretical Politics, 1:2, 149-76.

Schiller, Theo (2002), Direkte Demokratie. Eine Einfïhrung. Frankfurt a.M: Campus Verlag.

Schiller, Theo, and Volker Mittendorf, eds. (2002). Direkte Demokratie. Forschung und Perspektiven. Wiesbaden: Westdeutscher Verlag.

Schmidt, Manfred G. (2000). Demokratietheorien. Eine Einführung. Opladen: Leske und Budrich.

Schnell, Rainer (1994). Graphisch gestïtzte Datenanalyse. München: Oldenbourg.

Setälï, Maija (1999). Referendums and Democratic Government. Normative Theory and the Analysis of Institutions. Basingstoke: Macmillan Press.

Setälï, Maija (2006). 'On the Problems of Responsibility and Accountability in Referendums', European Journal of Political Research, 45:4, 699-721.

Shikano, Susumu, and Axel Becker (2004). 'Empirische Überprüfung von akteurszentrierten Koalitionsmodellen mit KOALA', paper presented at AK Handlungs- und Entscheidungstheorie des DVPW in Bamberg, 9 July, Universität Mannheim.

Smith, Gordon (1976). 'The Functional Properties of the Referendum', European Journal of Political Research, 4:1, 1-23.

Snyder, Richard (2001). 'Scaling Down: The Subnational Comparative Method', Studies in Comparative International Development, 36:1, 93-110. 
Sørensen, Eva, and Jacob Torfing (2007). 'Theoretical Approaches to Governance Network Dynamics', in Eva Sørensen, and Jacob Torfing (eds.), Theories of Democratic Network Governance. Houndmills: Palgrave Macmillan, 25-42.

Stutzer, Alois, and Bruno S. Frey (2000). 'Stärkere Volksrechte - zufriedenere Bürger: Eine mikroökonomische Untersuchung für die Schweiz', Swiss Political Science Review, 6:3, 1-30.

Suksi, Markku (1993). Bringing in the People. A Comparison of Constitutional Forms and Practices of the Referendum. Dordrecht: Martinus Nijhoff.

Tolbert, Caroline J., and Daniel.A. Smith (2006). 'Representation and Direct Democracy in the United States', Representation, 42:1, 25-44.

Trechsel, Alexander (2000). Feuerwerk Volksrechte. Die Volksabstimmungen in den schweizerischen Kantonen 1970-1996. Basel: Helbing und Lichtenhahn.

Troitzsch, Klaus G. (1979). Volksbegehren und Volksentscheid. Eine vergleichende Analyse direktdemokratischer Verfassungsinstitutionen unter besonderer Bertïcksichtigung der Bundesrepublik Deutschland und der Schweiz. Meisenheim am Glan: Hain.

Vatter, Adrian (2000). "Consensus and Direct Democracy: Conceptual and Empirical Linkages', European Journal of Political Research, 38:6, 171-92.

Vatter, Adrian (2002). Kantonale Demokratien im Vergleich. Entstehungsgründe, Interaktionen und Wirkungen politischer Institutionen in den Schweizer Kantonen. Opladen: Leske und Budrich.

Wagschal, Uwe (1999). Statistik für Politikwissenschaftler. München: Oldenbourg.

Weaver R., Kent, and Bert A. Rockman (1993). 'When and How Do Institutions Matter?', in R. Kent Weaver and Bert A. Rockman, (eds.), Do Institutions Matter? Government Capabilites in the United States and Abroad. Washington, DC: The Brookings Institution, 445-61.

Weixner, Bärbel (2002). Direkte Démokratie in den Bundesländern. Verfassungsrechtlicher und empirischer Befund aus politikwissenschaftlicher Sicht. Opladen: Leske und Budrich.

Weixner, Bärbel (2006). 'Direkte Demokratie in den Bundesländern', Aus Politik und Zeitgeschichte, 10, 18-24.

Wiegand, Hanns-Jürgen (2006). Direktdemokratische Elemente in der deutschen Verfassungsgeschichte. Berlin: Berliner Wissenschafts-Verlag. 
APPENDIX

OPERATIONALISATION OF VARIABLES

Variable
Initiative frequency in the
circulation stage
Quorum (circulation stage)
Circulation time (circulation
stage)
Mobilisation coefficient
(circulation stage)

Effective number of parties

Left party vote share

Governmental vote share

Number of government parties

\section{Hypothesis (ceteris paribus)}

As the quorum increases, fewer initiatives are expected.

As the circulation time increases, fewer initiatives are expected.

As the mobilisation coefficient increases the number of initiatives is expected to decrease.

As the number of effective parties increases, more initiatives are expected.

As the percentage of left parties in

government increases, more initiatives are expected, as the parties are said to favour direct democracy.

As the vote share for governmental parties increases, fewer initiatives are expected as more interests are represented.

As the number of parties in government increases, more interests are represented, so fewer initiatives are expected.

Operationalisation

Relative number of initiatives in

itiated per year

Signature requirement in percent of those entitled to vote in Land

parliament elections

Circulation time in days

Calculated after Moser (1985) who divides quorum by circulation divides

Calculated after Laakso and

Taagepera (1979)

Source

Statistical Land Offices, Land parliaments, Land election supervisors

Land constitutions, Land electoral laws

Land constitutions, Land electoral laws

Land constitutions, Land electoral laws

Statistical Land Offices, Land parliaments, Land election upervisors, Mielke and Reutter (2004)

Percentage of the vote share of left parties: SPD, Bündnis 90/Grüne PDS, SSW

Percentage of the vote share of parties in government parliaments, Land election supervisors, Mielke and Reutter (2004)

Statistical Land Offices, Land parliaments, Land election supervisors, Mielke and Reutter (2004)

Number of parties in government

information material 
APPENDIX 1

(Continued)

Variable

Turnout in Land parliament elections

Percentage of party members

Percentage of employees with union membership

Percentage of population doing voluntary work

Percentage of citizens working in an action committee

Total Land population

Urban 20

Third sector employees

\section{Hypothesis (ceteris paribus)}

As the voter turnout in Land parliamentary elections increases, the number of initiatives is expected to increase/decrease, as direct democracy serves as a compliment to/

substitute for representative democracy.

As the proportion of party members increases, the number of initiatives is expected to increase/decrease.

As the proportion of union members increases, the number of initiatives is expected to increase/decrease.

As the proportion of volunteers increases, the number of initiatives is expected to increase/decrease.

As the proportion of persons working in an action committee increases, the number of initiatives is expected to increase/decrease.

As the population increases, the number of initiatives is expected to increase, as growing individualisation supports procedures.

As the proportion of the population living in larer citios increase the number initiatives is expected to growing in expected to increase, as growing individuali

As the proportion of employees in the third sector increases, individualisation increase and the number of initiatives is expected

\section{Operationalisation}

Source

Voter turnout in Land parliament

elections

Proportion of party members (CDU/CSU, SPD, Bündnis 90/ Grüne, PDS)

Proportion of union members

Socio-economic panel (SOEP)

Proportion of population doing voluntary work

Proportion of citizens working in an action committee

Total Land population

Proportion of population living in cities with more than 20,000 inhabitants

Socio-economic panel (SOEP)

Socio-economic panel (SOEP)

Federal Statistical Office, Statistical Land Offices

Federal Statistical Office Statistical Land Offices

Percentage of employees in third sector

Federal Statistical Office Statistical Land Office 